\title{
Child's Life, Step-Family and Decision-Making Process
}

\author{
-European Overview
}

\author{
Susana Navas Navarro \\ Faculty of Law, Autonomous University of Barcelona, Cerdanyola del Vallès, Spain \\ Email: Susana.Navas@uab.cat
}

Received April $5^{\text {th }}, 2013$; revised May $6^{\text {th }}, 2013$; accepted May $15^{\text {th }}, 2013$

\begin{abstract}
Copyright (C) 2013 Susana Navas Navarro. This is an open access article distributed under the Creative Commons Attribution License, which permits unrestricted use, distribution, and reproduction in any medium, provided the original work is properly cited.
\end{abstract}

\begin{abstract}
Step-families are included within the concept of "family" used by both Art. 8 of the Rome Convention for the protection of Human Rights and Fundamental Freedoms and Art. 7 of the European Charter of Fundamental Rights of 2010. According to the OECD and EUROSTAT figures children that are living in step-families are between 8 and 12 years old, that is, they could be considered as preadolescents or in some cases adolescents at all. Thus, they are individuals with a certain grade of maturity that allow them to form their own views and express them. Today, there is an inevitable link between family and children's participation rights (Art. 12 CRC; Art. 24 EU Charter). Nevertheless, European Law refers to the step-family from the "adult's rights" viewpoint concerning the assignment of the parental responsibility to the step-parent neglecting children's perspective. As said by Art. 6(1) EU Treaty of Lisbon and by Art. 52(2) EU Charter, the last legal instrument has the same legal recognition as the EU Treaties, which implies that the bedrock for direct and vertical application of the fundamental rights of children by both the EUCJ and national Courts is settled. Since 2006 one of the strategic objectives of the communitarian institutions is prioritizing the effective implementation of children's rights.
\end{abstract}

Keywords: Children; Step-Family; Rights; European Union; Family Law

\section{Preliminary Remarks}

"Family" is not defined but referred by European Law. Case Law both the European Court of Human Rights (ECtHR) and the European Union Court of Justice (EUCJ) have shaped the concept of family including different forms of family lives (De Cruz, 2010; McGlynn, 2006; Sanz Caballero, 2006).

Dealing with the family leads necessarily to children and the rights that they are entitled to exercise within the family group (McGlynn, 2006). Family and child's rights are two aspects of the same social phenomenon that should be analysed together (McGlynn, 2006).

Before proceeding, we should determine the meaning that we confer to the term "European Law". We are relating to European Community Law and the legislation coming from other bodies such as the European Council. Within the European Community Law, we will focus on both "Primary and Secondary Law" as well as on "Soft Law", with particular regard, first, to the European Principles of Family Law Regarding Parental Responsibilities (EPFLRPR) (Boele-Woelki, Ferrand, González Beilfuss, Jänterä-Jareborg, Lowe, Martigny, \& Pintens, 2007) and, second, to the Model Family Code (MFC) (Schwenzer, 2006). We will also take into account the different national legal systems of the EU Member States in order to highlight the relevant legal instruments in the field of our research from a comparative viewpoint.

First of all, we will approach the question concerning the inclusion of the step-family within the European meaning of "family"; secondly, we will introduce the social picture of the step-family that emerge from the official European statistics data, third, we will examine the current legal references to the step-family in European Law (European Community Law and soft Law) emphasising the "adults' rights" point of view, which is that the lawmaker and scholars have taken into account as starting point of the existing and prospective regulation of the step-family. Finally, we will present some concluding observations giving due weigh to the future of the step-family in Europe and deserving special attention to the figures provided by the OECD ${ }^{1}$ and EUROSTAT.

\section{Family and Step-Family in European Law. Statistics Data}

The Convention for the Protection of Human Rights and Fundamental Freedoms, signed in Rome in 1950, shall be mentioned at the first place. Article 8, although it does not use the term "family", it is concerned with the term "family life" without offering a legal meaning of it.

The former international human rights instruments deserve relevance to the family as such. Indeed, the Universal Declaration of Human Rights of 10 December 1948, which is "customary international law" (Article 16(3)), considered that "the family is the natural and fundamental group unit of society and is entitled to protection by society and the state". Both the International Covenant on Civil and Political Rights of 1966, which came into force on the 23 March 1976, and the International Covenant on Economic, Social and Cultural Rights of 1966

${ }^{1}$ OECD means Organization for Economic Co-operation and Development. 
provided protection and assistance to the family as "the natural and fundamental group unit of society". For its own, the Convention on the Elimination of All Forms of Discrimination Against Women of 1979, that came into force in 1981, recognises the importance of the women's role within the family without prejudice to the role, that in an equal basis, the man plays.

The rule of the Rome Convention was reproduced by Article 8 of the Human Rights Act (HRA) of 1998, that states that "everyone has the right to respect for his private and family life, his home and his correspondence". "Family life" has been described as an "autonomous and freestanding" (De Cruz, 2010) concept that depends on the circumstances of each case allowing its broad interpretation. Within the concept of "family life" children's rights have deserved protection when their infringement has been alleged at ECtHR (Smith, 2008), which has assessed that the HRA is a "living instrument" that requires interpretation in the light of social changes (Keegan v. Ireland A/ 290, 1994, 18 EHRR 342; Marckx v. Belgium A/31, 1979, 2 EHRR 330; Selmouni v. France, 2000, 29 EHRR 403).

By the HRA, the Charter of Fundamental Rights of the European Union ${ }^{2}$ (EU Charter) rules the same rights as they have been settled. In particular, Article 7 refers to the right to a personal and family life (Article 8 Rome Convention) and Article 9 is concerned with the right to marry and found a family (Article 9 Rome Convention). As these norms correspond to those of the Rome Convention, they shall be interpreted by the Courts in the same fashion as the aforementioned rules (Article 52(3) EU Charter), without prejudice to more favourable provisions of Community Law, in which case the application of these should prevail over the case Law. Moreover, Article 33(1) of the EU Charter asserts that "family shall enjoy legal, economic and social protection".

As it has been highlighted by scholars, the "pattern of the family" - and that of the child- that is taken into account by the EU Charter is a traditional and conservative model (McGlynn, 2006). Indeed, the angle from which family is seen by Community legislator is basically a heterosexual marriagebased family where the mother is the main carer of the child, who is regarded as a person needing help and protection rather than as an independent and autonomous human being, who can express his or her own opinion. This approach is evident in Article 24 EU Charter that strengths, at the first place, the care and protection of the child, leaving the best interests of the child principle to a second place. Article 3 of the Convention on the Rights of the Child (CRC) does the opposite: first, the best interest of the child principle has to deserve a paramount consideration, then, the right of protection and care is stressed.

Both family and child pattern, that it could be criticised, are, nevertheless, in accordance with the statistics data that in family issues have been provided by the OECD and EUROSTAT. This second agency, coinciding substantially with the former ${ }^{3}$, remarks how the highest rate of children is living in households where the parents are married to each other. Therefore, in Europe most of the families are marriage-based. The average of heterosexual marriage-based families for Europe- 25 is $73,8 \%$ (Eurostat, 2010), figure that address that, although new forms

${ }^{2}$ DOUE $2010 / C$ 83/02.

${ }^{3}$ In the OECD-22 the rate of children living in heterosexual marriage family-based is of $82.9 \%$.

(http://www.oecd.org/els/socialpoliciesanddata/41919533.pdf). Last checked: of 5 April 2013 of family lives have emerged and are still emerging, that based on heterosexual marriage is clearly predominant. In addition, if we focus on the men contribution to the care of the children (either of both spouses or of one spouse) and other household tasks, we will appreciate that in the EU-27 women spend more hours a week on these than men do. In 2009, in Holland, Switzerland and Scandinavian countries, women engaged in housework 16 hours a week, whereas men were engaging just 8 hours. In Belgium, Germany, France, Luxemburg and Austria figures arise that women are concerned with family tasks 3.6 hours a week while men only 9.5. The most important gap is found in Ireland and the United Kingdom, where women spend 14.2 hours a week, as long as men spend just 4.1 hours. Those rates are consistent with the fact that in the EU-27, 2.9\% of part-time jobs are taken by men and $24.7 \%$ by women. They have argued that their limited participation in the labour market is, firstly, the result of engaging in the care of their children and secondly, because of not finding a full-time job (Eurostat, 2009).

Thus, we consider that, though controversial, European Law reflects the lifestyle that most of European citizens have chosen.

Despite this preference, new family lifestyles, as we point out above, are becoming more evident in Europe due not only to the fact that single parents and heterosexual and homosexual civil partnership are nowadays admitted in all countries, but also because most of the countries allow homosexual marriages. In addition, separation and divorce have become a commonplace in Europe. Therefore, some of these new families are "second families" where children of both spouses or civil partners are living with those of one spouse or civil partner. Step-families are a reality in Europe. However, there is no specific statistical data concerning them because they are included in the most general figures for marriage and partnership based families, without distinction if it is a former, second or even, in some rare cases, third families (Eurostat, 2010).

A mention, albeit indirect, to step-families is found in Article 3(2) and Article 5 CRC. In these rules, the CRC obliges States to ensure the necessary protection and care for the child's welfare taking into account the rights and duties of legal parents or a third person, who has parental responsibility over the child. This third person could be, according to the national jurisdictions, a step-parent.

Even though the EU Charter uses the term "family" in singular, Europe does not ignore a pluralistic (Beck-Gernsheim, 2002) concept of it, which has often been reflected in both the ECtHR and EUCJ case Law (Sanz Caballero, 2006). If we focus on step-families, two leading cases deserve due attention: Bambert and R. v. Secretary of State (C-413/99, ECR I-7091) and Carpenter v. Secretary of State (C-60/00, ECR I-6279). In the former it was considered that the step-child should be treated as a member of the migrant worker's family for the purpose of his right of residence in a EU member state in order to follow his education, and, in the second one, the Court ruled that the interests of Mr. Carpenter's son are perfectly assisted by the right to a "family life", a fundamental right recognised and protected by Community Law.

Concerning the ECtHR, the Kroon v. Netherlands (1995, 19 EHRR) case should be stressed concerning a step-family in which the partners do not live on a regular basis together. It is worth to note that the partner of the mother of the children economically contributed to their maintenance and was emotionally attached to them (Sanz Caballero, 2006). The ECtHR 
understood that in this case "family life" still exists and thus could be protected under Article 8 HRA 1998 (McGlynn, 2006).

\section{A Social Picture of the Step-Family in Europe}

Nowadays there are many types of step-families, albeit originally it was considered as such the family in which at least one spouse or partner had already been married before and children from the previous personal relationship are living in the dwelling, together with newborn children of both spouses or partners (Wardle, 1993; Berstein, 1999). To this family was added, first, the family where one of the spouse or partner had already been in a civil partnership and, second, the single parent that lives together with another person in a marital or nonmarital based relationship (Goldscheider \& Sassler, 2006; Nelson, 2006; Sarkisian, 2006). The central elements of all of these forms of family life is that they are based on the existence of a marital or non-marital relationship - both homosexual and heterosexual - and on the presence of children of both spouses or partners or of one of them.

If we handle at this moment with the statistics data provided by the EUROSTAT ${ }^{4}$, between years 2006 and 2010, it turned out that, although more marriages than civil partnerships were established, in the EU-27 the rate of marriages has decreased whereas divorces are increasingly commonplace. In this topic, a relevant difference between northern and southern countries in Europe can be appreciated. Whereas in northern countries civil partnerships have increased, in southern countries there is a higher trend to marry (Eurostat, 2010) ${ }^{5}$.

The marriages between single people are still frequent, however second marriages have become more and more usual. Figures do not take into account the existence of step-children in "second families". When we look at the statistical data provided by the OECD - based on statistical data given by the EUROSTAT - arise that the average age for the former marriage is 32 years old for men and 29 to 30 years old for women ${ }^{6}$ and the average age for divorce is between 40 and 45 years old for both men and women, that is, the breakup of the relationship arises between 10 and 15 years after the former marriage ${ }^{7}$. These rates shall be supplemented by the average age for women to give birth to their first child that, in the EU-27, is between 29 and 34 years old ${ }^{8}$. What is being suggested here is that when people marry for second time, they probably have children around 8 and 12 years old. Therefore, in second families, there are children (mostly, step-children) that could be regarded as preadolescents or adolescents, that is, children with a certain grade of maturity permitting them to be able to form their own views and express them.

Nevertheless, the model of the "child" in Europe is still, as

\footnotetext{
${ }^{4}$ http://epp.eurostat.ec.europa.eu/portal/page/portal/eurostat/home

${ }^{5}$ The rate of the decrease of marriages at the OECD countries between 1970 and 2009 could be looked up at:

http://www.oecd.org/els/familiesandchildren/SF3.1\%20Marriage $\% 20$ and $\% 2$ 0divorce $\% 20$ rate $\% 20-\% 20$ updated $\% 20240212$.pdf. Last checked: of 5 April 2013.

${ }^{6}$ http://www.oecd.org/els/familiesandchildren/SF3.1\%20Marriage $\% 20$ and $\%$ 20divorce $\% 20$ rate $\% 20-\% 20$ updated $\% 20240212$.pdf. Last checked: of 5 April 2013.

${ }^{7}$ http://www.oecd.org/els/familiesandchildren/SF3.1\%20Marriage $\% 20$ and $\%$ 20divorce\%20rate\%20-\%20updated\%20240212.pdf. Last checked: of 5 April 2013.

${ }^{8}$ http://epp.eurostat.ec.europa.eu/cache/ITY_OFFPUB/KS-EH-06-001/EN/K S-EH-06-001-EN.PDF. Last checked: of 5 April 2013.
}

we have highlighted when we were looking at the "family pattern", a traditional and conservative one, in which the child is viewed as depending on an adult and needing of special assistance. This child pattern still exists despite of relevant legal milestones such as the CRC or the EU Charter. A timid attempt to modify this could be found in the EPFLRPR 3:4 and in Article 3(25) MFC ("Autonomy of the child": The child's autonomy should be respected in accordance with the developing ability and need of the child to act independently), even though there are still some steps to go forward.

The self-determination and the best interests of the child principles are recognized in all of the European national legal systems (Boele-Woelki, Braat, \& Curry-Sumner, 2005), albeit, they have been deprived of real implementation. Because of this, the European Commission in the Communication on Strategic Objectives 2005-2009 ${ }^{9}$, has stressed that the rights of children are one of its priorities, considering that they should not simply be subsumed in the more general human rights. Prospective actions taken by the European Union, concerning children's rights, have been prescribed in the Commission' Communication Towards an EU Strategy on the Rights of the Child, whereby an appeal is made to Member States, communitarian institutions and other bodies to play an active role in the development of this strategy as a means of consolidating the European integration ${ }^{10}$. Then, if it is still necessary to raise the implementation of children's rights in terms of strategy, it is because they are not implemented effectively.

Adults and children have cross-cultural views relating children's rights. Indeed, adults tend to focus on their duty of child's maintenance while children have other perspective based on their autonomy, independence and self-determination. They are concerned with the "free development of their personality". As rightly said by Eekelaar (1986), children are holders of a variety of "interests", in particular, three: first, the primary ones related to the maintenance of the child (nurture, education, medical care, etc.); second, those regarding the personal development and, third, concerning the personal autonomy. The former two are the backbone of the "welfare of the child". In the scholars' opinion, the development of the child's personality is a fundamental interest of him or her in order to be competent for exercising his or her right of self-determination and to participate in the decision-making process. Adults have been (and still are) reluctant to recognise and act according to these interests that are seen as a mainstream by children (Eekelaar, 2006).

From the adults' perspective, personal relationships with children are "hierarchical"-based and they present a remarkable "paternalistic" profile. From the children point of view, personal relationships are conceived on individualism, on human rights, and in particular, on personal freedoms. They do not seek to separate themselves from their families, instead they regard themselves as independent individuals in order to participate in the decision making process in matters that affect their personal life (Cherney, Greteman, \& Traves, 2008).

\section{Current European Legal References to the Step-Family from the Viewpoint of the "Adults' Rights"}

In this section importance is attached to the current European legal references in relation to the step-family: from Community

${ }^{9} \mathrm{COM}(2005), 12$.

${ }^{10} \mathrm{COM}(2006), 367$ final. 
Law to European family soft law, coming across the different European jurisdictions. In all of these systems it is clear that the regulation of the step-family is made from an "adults' rights" point of view, hardly regarding the child's welfare, the best interests of the child principle or the children's rights, despite the relevant section that in all of the national Acts and Statutes regulating children's rights these principles deserve.

So, first we will deal with the Community Law, secondly, we will treated the regulation of the step-family in the European national legal systems and thirdly, we will outline the family soft law, in which the difficulties in order to obtain from the different European legal traditions common core elements are addressed.

\section{Community Law}

Step-families have deserved some attention in Community Law. Indeed, firstly, we should refer to Article 2(2) lit. c of the Council Directive 2004/58/EC, of 29 April 2004, on the rights of citizens of the Union and their family members to move and reside freely within the territory of the Member States amending regulation", which when using the term "direct descendent", for the purpose of this Directive, despite its ambiguity, means "who are under age of 21 or are dependants and those of the spouse or partner". So, it means "step-children".

At the second place, it is worth to allude to a family reunification case, Article 4(1) lit. c and lit. d of the Council Directive 2003/86/EC, of 22 September 2003, on the right to family reunification $^{12}$ that takes into account-indirectly- the reunification in step-families when the sponsor shares custody of the child minor provided that the other party sharing custody has given her or his agreement. We should remind that children have the right to maintain direct contact and on a regular basis a personal relationship with both his or her parents (Article 24(3) EU Charter).

The aforementioned two Directives take an adult-centered approach. Indeed, the legislator made provisions on the rights of the adult either to move freely through the EU member states or to reunify his or her family. The child has the right to maintain direct contact with both his or her parents and with other family members and relatives, in spite of European national legislators that, in fact, consider this right as a right of the adult to maintain direct contact with the child. The positive right of the adult has also a negative side; that is the right to not maintain a personal relationship with the child, even to the extreme that parents can give the child for adoption. The negative right to not maintain a personal relationship with the adult is not recognized to the child at all.

Now, let us focus on the norms that will "communitarize"13 International Private Law (Cano Bazaga; McGlynn, 2006): we should underline, first, the Brussels Treaty II of 28 May 1998 on jurisdiction, recognition and enforcement of judgments in matrimonial matters and matters of parental responsibility ${ }^{14}$, that was in its turn substituted by the Council Regulation (EC)

\footnotetext{
${ }^{11}$ DOUE 2004, L 229/35.

${ }^{12}$ Council Directive $2003 / 86 / \mathrm{CE}$, of 22 September 2003, on the right to family reunification (DOUE 2003, L 251/12).

${ }^{13}$ The EU has assumed exclusive competences for the conclusion of International Conventions with third parties that concern matters ruled in communitarian Regulations.

${ }^{14} \mathrm{http}: / /$ europa.eu/legislation_summaries/justice_freedom_security/judicial_c ooperation_in_civil_matters/133194_en.htm. Last checked: of 5 April 2013.
}

1347/2000 of 19 May on jurisdiction and the recognition and enforcement of judgments in matrimonial matters and in matters of parental responsibility for children of both spouses ${ }^{15}$, whose Art. 3 does not refer to step-families but does use the term "parental responsibility" in a broader sense in order to include a plurality of persons that could be considered holders of the parental responsibility, including step-parents. This Regulation was also repealed by the Council Regulation 2201/ 2003 of 27 November, concerning jurisdiction and the recognition and enforcement of judgments in matrimonial matters and the matters of parental responsibility ${ }^{16}$ (Article 2(7)) that rules, like the abrogated norms, a marriage based family, in which there are children of both spouses. There is no mention to stepfamilies; in spite of the employ of the term "parental responsibility" has became a commonplace.

In July 2006 the Proposal for the Regulation amending Brussels II bis as regards jurisdiction and introducing rules concerning the applicable law in matrimonial matters ${ }^{17}$ was approved. However, the Proposal did not amend the Council Regulation concerning parental responsibility.

At international level The Hague Convention on Jurisdiction, Applicable Law, Recognition, Enforcement and Co-operation in Respect of Parental responsibility and Measures for the Protection of Children of 19 October $1996^{18}$, in Article 1(2), provides that "parental responsibility" includes parental authority or any analogous relationship of authority determining rights, powers and responsibilities of parents, guardians or other legal representatives in relation to the person or the property of the child $^{19}$. On 25 January 1996 the European Convention on the exercise of children's rights was approved and Article 2 lit. b states that "parental responsibility" means "parents and other persons or bodies entitled to exercise some or all parental responsibilities".

In the Community Regulations we should distinguish, on the one hand, the family pattern taken into account from, on the other hand, the parental responsibility. Indeed, the parental responsibility is expanded beyond its originally limited definition and legal parents and other persons could be regarded as holders. However, to become a holder of the parental responsibility does not mean necessarily to found a family with the child.

When a second family is concerned, the family pattern that is also outlined by these Council Directives is a traditional conservative heterosexual marriage-based family, in which the adults' rights viewpoint deserved special attention. It could be said that the CRC and the EU Charter have not had too much influence on these rules.

\section{Regulation of the Step-Family in the European Jurisdictions}

First of all, we will expose the legal meaning of "parental responsibility", secondly, we will focus on how the different European jurisdictions assign parental responsibility to the step-parents and last but not least, we will provide some references concerning the adoption of the step-child.

\footnotetext{
${ }^{15}$ DOCE L 160, of 30 June 2000.

${ }^{16}$ DOCE L 338, of 23 December 2003.

${ }^{17} \operatorname{COM}(2006) 399$ final.

${ }^{18} \mathrm{http}: / /$ www.hcch.net/index en.php?act=conventions.text\&cid=70. Last checked: of 5 April 2013.

${ }^{19}$ European Treaty Series, n.160.
} 


\section{The Legal Meaning of Parental Responsibility}

"Parental responsibility" is mostly regulated in the European national legal systems within the Civil Code. Austria, Belgium, France, Germany, Spain, Italy, Greece, Lithuania, Portugal, Holland and Switzerland are an example of this lawmaking policy. Parental responsibility is also regulated within the Family Code like in Bulgaria, Czech Republic, Hungary and Russia. On the other hand, Denmark, Ireland, England and Wales, Finland, Norway and Sweden (Boele-Woelki, Braat, \& Curry-Sumner, 2005) have regulated "parental responsibility" either in specific rules concerning children's rights, parental authority, custody or guardianship Acts.

The employ of the term "parental responsibility" stems from the Common Law tradition, in particular, from the sec. 30 of the Children Act of Norway of $1981^{20}$. Later it was used by the Recommendation n. R. (84) 4 of Europe's Council on parental responsibilities ${ }^{21}$ and by the United Kingdom's Children Act of 1989 (sec. 2). In the last legal system, by using this term, the legislator declares that, on the one hand, parents have rights as well as duties over their children and, on the other hand, that parents were entitled instead of the State (Eekelaar, 1991) to fulfil these duties. In this sense, sec. 3 (1) provides, regardless of its ambiguity, the following content of "parental responsibility" (Freeman, 2010): "all the rights, duties, powers, responsibilities and authority which by law a parent of a child has in relation to the child and his property" 22 .

The term "parental responsibility" is also used in $\S 31$ of the Czech Family Code, in Irish Law [Children (Northern Ireland) Order 1995] and, since 2008, in Portuguese Law (Código Civil).

The above mentioned content of the parental responsibility ${ }^{23}$ corresponds, for instance, to the content of the term "autorité parentale" used in France (Code civil), of the term "Elterliche Sorge" employed in Germany (BGB) and, of the "patria potestad" admitted in Spain (Código Civil). The term "parental authority" with the same meaning as "parental responsibility" is accepted in Denmark (Danish Act on Parental Authority and Contact of 1996), Italy (Codice Civile), Lithuania (Civil Code of 2001), Holland (Dutch Civil Code), Poland (Family and Guardianship Code of 1964) and Switzerland. "Parental care and guardianship" is instead the term employed in Greece, "parental rights" in Russia (New Russian Family Code of 1995) and "parental rights and obligations" in Bulgaria (Child Protection Act of 2003).

In other European legal systems the legal wording is "custody" or "care". This is the case of Austria (ABGB: Obsorge), Finland (Finish Child Protection Act) and Sweden (Lowe, 2009).

Hence, parental responsibility means "all the duties, rights and powers over the child".

Due to the fact that the term parental responsibility is admit-

\footnotetext{
${ }^{20} \mathrm{http} / / /$ www.regjeringen.no/en/doc/Laws/Acts/The-Children-Act.html?id=4 48389. Last checked: of 5 April 2013.

${ }^{21} \mathrm{http}: / /$ www.coe.int/t/dghl/standardsetting/equality/03themes/women-media /Rec 8417 en.pdf. Last checked: of 5 April 2013.

${ }^{22} \mathrm{~A}$ list of the most important rights and duties included within the content of "parental responsibility" could be read at the Children (Scotland) Act 1995 in sec. 2 (1). This Act could be checked at:

http://www.legislation.gov.uk/ukpga/1995/36/section/1. Last checked: of 5 April 2013.

${ }^{23}$ Some legal instruments has used the term both in singular and plural, but this indistinct use does not bring any particular legal consequence in order to the most accurate interpretation of it.
}

ted by international and European legal instruments, it could be understandable that scholars when considering harmonizing Family Law in Europe have taken it into account as we will then see.

Regarding the holders, most of these norms attribute the parental responsibility either to the legal parents or/and to the step-parent. As we will expose in the next section, this attribution differs among the European jurisdictions. For instance, in English Law, more than one person can be simultaneously holder of the parental responsibility over the same child. Sec. 2 of the Children Act of 1989 states that:

"(5) More than one person may have parental responsibility for the same child at the same time. (6) A person who has parental responsibility for a child at any time shall not cease to have that responsibility solely because some other person subsequently acquires parental responsibility for the child".

Nevertheless, there are some relevant differences between European jurisdictions relating the legal status of the step-parents when it is compared with that of the legal parents of the child. Indeed, while in some jurisdictions, like those of the Common Law tradition, they have almost the same legal status; other jurisdictions, like those comprised in the German-French tradition, make important distinctions between them in order to assign parental responsibility. This question will be developed in the next section.

\section{Assignment of Parental Responsibility}

The European national legal systems, as we have already affirmed, do not ignore step-families, and, even though they have been variously regulated, all of them have as a common feature that the regulation is made from an adult-centred approach.

According to the legal policy of each EU member state, we first find some legal systems, in which the State, hand by hand with the legislator, has directly attributed to the step-parent the right to participate in the decision-making process concerning child's daily matters. Therefore, in this case, the State establishes a personal relationship between the child and the stepparent. At the second place, there are some legal systems, in which what is given by the legislator, in accordance with the State, to the step-parent is the right to set up a personal relationship with the child. Thus, here the relationship is not directly - albeit indirectly — constituted by the State. Third, outcomes of this overview will be expose.

The state directly recognises parental responsibility to the step-parent.

State could set up a personal relationship between the child and the step-parent according to two patterns: 1) the attribution of the exercise of some parental responsibilities to the stepparent "in addition" to legal parents or third persons; 2) the attribution of the parental responsibility to the step-parent "instead of" the legal parents as an alternative to child's adoption.

Concerning the first pattern, it is worth to regard the German legal system, the Swiss legal system and some of the Regional legal systems in Spain. Approaching the first jurisdiction, we should consider $\S 1687$ BGB (Sorgerechtliche Befugnisse des Ehegatte) ${ }^{24}$ and $\S 9$ (1-4) LPartG (Regelungen in Bezug auf Kinder eines Lebenspartner $)^{25}$. The former is referring to the spouses and the second to the registered homosexual partners.

\footnotetext{
${ }^{24}$ The German Civil Code (BGB) was amended in 2001 by the LPartG (see next footnote), in order to insert this right into the regulation of the "parental responsibility".
} 
Both legal instruments state the right of spouse or the partner of the parent of the child in order to participate in the decision making-process in matters that concern the daily child's life. This right is described by German scholars as a "kleines Sorgerecht", that is, "small parental responsibility" 26 .

Article 299 of the Swiss Civil Code settles that the stepparent has the fundamental duty to assist his or her spouse, legal parent of the child, who is the holder of the parental responsibility. Thus, the participation of the step-parent is due to the fact that he or she should fulfil a matrimonial duty. $\S 33$ of the Czech Family Code has taken the same legal approach when regulating the participation of the step-parent in matters regarding the child of the spouse or partner.

Swiss scholars consider, when interpreting the wording of Article 299 of the Swiss Civil Code that, in this case, the legal status of the step-parent is similar to that of the "foster parent" (Schwenzer, 2002). For the Austrian legislator (§ 186a Austrian Civil Code) the step-parent is considered indeed as a "foster parent", as well.

Within the Spanish legal system we should highlight two Regional Laws: first, the Catalan Civil Code and second, the Foral Civil Code of Aragon. Both Civil Codes settle the right of the step-parent over the step-child into the legal framework of "parental responsibility".

If we deal at this moment in-depth with the aforementioned second pattern of attribution of the parental responsibility, the feature of it should be outlined. Indeed, it concerns the fact that the step-parent has the same legal status as the legal parent of the child, what means that he or she has the right to participate in the decision-making process relating all matters that affect child' life. The step-parent is also concerned with the legal representation of the step-child. So, the step-parent is acting "instead of" the other legal parent. Usually, European jurisdictions accept this model of assignment of parental responsibility to the step-parent provided that the parental responsibility of the other legal parent ends up. This pattern of attribution is admitted in Bulgaria as long as the parenthood of the other parent of the child was not legally determined, in Lithuania whenever the child was recognized by the biological parent that is married or currently cohabiting with the step-parent and in The Netherlands, where the parental responsibility is assigned to the step-parent providing that parenthood with the other biological parent was not assessed (Boeli-Woelki, Braat, \& CurrySumner, 2005).

There are relevant differences concerning legal effects between both models of assignment of parental responsibility to the step-parent. Actually, when the attribution relates to the exercise of some parental responsibilities, the step-parent is just concerned by some kind of matters, those regarding daily and urgent matters. The step-parent is entitled to act "in addition" to both legal parents and not "instead of" them, which means in its turn that the step-parent is not considered as a legal representative of the minor. The step-parent cannot conclude contracts as a legal representative of the minor. His or her participation in daily and urgent matters of the step-child concerns just factual acts. This does not mean that the step-parent cannot contract, he

\footnotetext{
${ }^{25}$ Gesetz über die Eingetragene Lebenspartnerschaft (Lebenspartnerschaftsgesetz-LPartG), of 16 February (BGB1. I, p. 266). The last amendment of this Act has been done by Art.7 of the Act of 6 July 2009 (BGB1. I, p. 1696). ${ }^{26}$ This term was given by the Commission that drafted the rule (BT-Drucks 14/3751, p. 39)
}

or she will do it in his or her own name (instead of on behalf of the child), albeit the benefits of these contracts results in the child best interest.

The step-parent has not a duty to maintain the step-child, though in some European legal systems the lack of this duty is controversial. In relation to the duty of maintenance of the step-parent in the case of the attribution of the exercise of parental responsibilities "in addition" to the legal parents, the European national legal systems do not have a uniform regulation. Some of them have gradually admitted the existence of this duty of the step-parent, when the step-child is a minor, i.e., Dutch Civil Code, Swiss Civil Code, Swiss Same-Sex Registered Partnership Act of 18 June 2004, Children Act 1989 of the UK and the Child Support Act 1991-1995 ${ }^{27}$ (Navas Navarro, 2010; Sosson, 1993).

In accordance with the second model of step-parent's parental responsibility attribution, step-parent acts "instead of" the legal parent. Hence, the step-parent is a legal representative of the child, together with his or her spouse or partner, and can take decisions concerning all of (personal and patrimonial) matters that affect him or her.

The exercise of the parental responsibilities is conceived in both patterns as an adult's right, what means that the adult can decided or not to exercise this right. So, the regulation is adult's rights-centred.

On the other hand, relating the step-child, he or she has the right to be informed and to be heard (Article $12 \mathrm{CRC}$, Article 24(2) EU Charter). However, these rights will be fulfilled only when the adult decides to take "decisions" concerning child's daily matters inspired by his or her "best interests" (Article 3 CRC, Article 24(2) EU Charter) and often the child is informed and heard after the decision is taken and the adults have acted. Moreover, the legal regulation of the step-family made by the European lawmakers have left aside the participation of the child in the law drafting process itself.

Ultimately, the regulation of the step-family is paternalistic. It is aimed "to protect" the child or "to assist" the legal parent of him or her. It is not drafted from the child's right viewpoint in order to want or not that a third person take decisions relating his or her personal life. In fact, it should be the child, who is entitled to take this kind of decision if above all we keep in mind that most of the step-children could be regarded, according to the exposed official European figures, as pre- and adolescents.

The state directly recognizes the right of the step-parent to require the assignment of parental responsibility.

If we give attention to the recognition of the right of the step-parent to require the assignment of parental responsibility, from the European national legal systems arises that there are also two patterns in order to attribute this right. First of all, by permitting that legal parents of the child and step-parents reach an agreement whereby the step-parent is entitled to have in whole or in part parental responsibilities over the child. This agreement is based on the free will principle. However, in most of the EU legal systems this kind of agreement concerning the parental responsibility is prohibited because this matter is subjected to the "ordre public" clause. This is the case, for instance, of Germany, Austria, Bulgaria, Spain, Finland, France, Greece, Hungary, England and Wales, Ireland, Italy, Lithuania, Norway, Poland, Portugal, Russia, Sweden and Switzerland. Neverthe-

${ }^{27}$ http://www.opsi.gov.uk/Acts/acts1991/ukpga_19910048_en_1. Last checked: of 5 April 2013 
less, article 475 ter of the Belgium Civil Code states that most of the parental responsibilities could be attributed to the step-parent by agreement whereas the child, minor of 15 years old, consents this attribution. In Denmark is also permitted the attribution of parental responsibility by agreement provided that the competent Court approved it by an "order" (Lowe, 2009).

The content of such an agreement is twofold. Indeed, it could be referred, on the one hand, to the attribution of the parental responsibility "instead of" the legal parents of the child as in Belgium and Denmark and, on the other hand, to the attribution of the exercise of some parental responsibilities "in addition to" or "instead of" the legal parents. This is the case of the British legal system. Section 4A of the Children Act, which was amended by the Adoption and Children Act in 2002 and by the Civil Partnership Act in 2004, rules the agreement whereby the legal parents of the child can attribute the exercise of some of the parental responsibilities to a third person as long as the child lives together with him or her. Consequently, more than one person (a "parenting team") takes decisions concerning child' personal life that, in the same matter, could potentially come into conflict. Then, the regulation of the step-families from the adult's rights point of view turns against the welfare of the child (Eekelaar, 1998).

The second way for the State to attribute the right of the step-parent to require the assignment of the parental responsibility over the child is by permitting that the step-parent applies to a Court in order to have the parental responsibility by means of an "order". The content of this "order" could be, as we have described, twofold: 1) it concerns the exercise of some parental responsibilities "instead of" or "in addition to" the legal parents of the child or 2) it could be regarded the assignment of the parental responsibility as such "instead of" the legal parents, that is, the step-parent is considered as a holder of the parental responsibility. In Finland and France if the step-parents will have some kind of parental responsibility over the step-child they shall bring a lawsuit to the Court in order to be a holder of some parental responsibilities in addition to the legal parents. For its own, in Austria due to the fact that step-parents have the same rights and duties as foster parents, they are entitled to be holders of the parental responsibility instead of the legal parents. However, it shall be attributed by an "order" of the Court (Boele-Woelki, Ferrand, González Beilfuss, Jänterä-Jareborg, Lowe, Martiny \& Pintens, 2007). British, Scottish and Norwegian Law rules also this pattern of attribution of the parental responsibility by means of a "residence order". For instance, it is so states in sec. 12 of the British Children Act of 1989. The "residence order" prescribes the person the child will live together with (Harris-Short \& Miles, 2007).

\section{Outcome.}

The fact that the step-child lives together with the step-parent is a requirement of the assignment of the parental responsibility by the State in the variety of patterns that we have already ex$\operatorname{posed}^{28}$. However, this requirement is seen as a "residence", that is, the place where the child actually lives, as distinguished from the "domicile" of the child that could be fixed in the place where one legal parent is currently living. This means bodily presence of the child always or for some periods of time at the step-parent's home. It should be realised that depending on the facts, the legal parent of the child, who is married with the

\footnotetext{
${ }^{28}$ See "The State directly recognizes parental responsibility to the step-parent" and "The State directly recognizes the right of the step-parent to require the assignment of parental responsibility" of this paper.
}

step-parent or has entered into a civil partnership with him or her, could have joint or share parental responsibility with the other child' legal parent.

So, the adult takes decisions affecting daily matters of the step-child, when he or she is currently living with.

European national legal systems do not require for attributing to the step-parent parental responsibility of a minimum period of time, in which step-parent and step-child live with. Hence, as alternative requirement to this, German Law ( $\S 1687$ b Abs. 4 BGB and $\S$ Abs. 4 LPartG), for instance, provides that the participation of the step-parent in the decision-making process is only valid if the legal parent of the child, who is currently living with, consents such participation.

In our view, the requirements of a minimum period of time currently living with the step-child and step-parent shall be seen as conform to the welfare of the child. Indeed, living in a stepfamily is not precisely easy, or not usually so, in particular, when children of different ages (Bar-Hava \& Pryor, 1998; Schwebel \& Fine, 1991; Edwards, 2002; Manning, Smock, \& Majumdar, 2004; Melli \& Brown, 2008) are living in and when the question about who should economically maintain the step-child arises. Nevertheless, legislators have kept in mind a picture of the step-family that is not corresponding to the "true" step-family. They think in a well-established family in which all of its members are happy and they have excellent personal relationships to each other. The social facts show the opposite. So, would it not have been more respectful to the welfare of the child if the lawmakers have required some kind of period of time of living with in order to attribute parental responsibilities to the step-parent? Once again, we should stress that rules are made from the adult's and not from the child's best interest point of view.

Anyhow, we consider that a true regard to the child's rights in this field, as well as in other matters concerning him or her, is only possible if we take seriously into account the participation of the child in the decision-making process, that is, the child having sufficient understanding and in any case when he or she reach a minimum age, should have the opportunity to take decisions, which means that he or she should bearing the consequences that are attached to his or her decision. In our opinion, this is nowadays the only way to bring up children in a global world. This is the only way to make that children become adults' citizens, when they realize the consequences of their decisions and take responsibility for them. In conclusion, the question deals with the respect of the fundamental rights of the child that all European legal instruments recognize.

\section{Adoption of the Step-Child}

The adoption by the spouse or partner of the legal parent of the child, whether legal requirements are fulfilled, is in whole Europe a recognized choice in order to attribute parental responsibility to the step-parent. As known, give a child for adoption supposes that the personal relationship with the other (biological or adoptive) legal parent ends up. In all European countries, the consent of the legal parents, the consent of the step-parent and the consent of the child, whereas he or she has sufficient understanding and a minimum age, is required. When adoption is given the step-parent becomes "legal parent" and his or her legal status is the same as the other child' legal parent living with.

However, we could find some differences between European legal systems relating the adoption' requirements. Indeed, in 
Belgium, Denmark, the Netherlands, Sweden and Germany it is required that step-parent and the legal parent of the child are married. As a reminder, homosexual marriage is at the present admitted in Spain, Belgium, France, Denmark, Sweden, Norwegian, Portugal, Iceland and The Netherlands (Navas Navarro, 2006). The Parliament of England is currently discussing the possibility to admit homosexual marriage as well.

In Spain, England, Wales and Scotland the homosexual or heterosexual civil partner of the child' legal parent is legally entitled to adopt the child (Boele-Woelki, Ferrand, González Beilfuss, Jänterä-Jareborg, Lowe, Martiny, \& Pintens, 2007). In the opposite, Austria, Lithuania, Portugal, Italy and Czech Republic accept only that the child should be adopted by the heterosexual civil partner of the child' legal parent, whereas Bulgaria, Greece, Hungary, Poland and Russia do not have a specific rule concerning such a requirement (Boele-Woelki, Ferrand, González Beilfuss, Jänterä-Jareborg, Lowe, Martiny, \& Pintens, 2007).

\section{Soft Law: European Principles of Family Law Regarding Parental Responsibilities and Model Family Code}

The content of the parental responsibility regardless of whether the holders thereof are the legal parents of the child or third parties, including the step-parent, is provided by the EPFLRPR 3:19, which settles that:

"(1) The holder of parental responsibilities should provide the child with care, protection and education in accordance with the child's distinctive character and developmental needs".

The step-parent as a holder of parental responsibility is, in particular, contemplated in EPFLRPR 3:2 (2) (b) as a "person other than the child's parents having parental responsibilities in addition to or instead of the parents".

This EPFLRPR shall be supplemented with the EPFLRPR 3:9 whereby third persons may have parental responsibilities "in whole or in part".

The EPFLRPR have admitted the above described two European models of having parental responsibility by the stepparent. Indeed, EPFLRPR 3:17 states that the step-parent is entitled to have parental responsibility in "addition to" or "instead of" the legal parents. On the contrary, EPFLRPR 3:18 settles the right of the parent's partner or spouse living with the child to take part in decisions with respect to daily matters as an exercise of some of parental responsibilities, but not as a holder as such. This participation of the step-parent is subjected to the fact that the other parent having parental responsibilities does not object.

Meanwhile, Article 3(28) MFC on parental responsibility of third parties, warns as the EPFLRPR that only the competent authority can vest parental responsibility in a third party, "in addition to" or "instead of" legal parents 1) the child has lived with this third party for more than 3 years and the third party request parental responsibility or 2) as a measure of child protection (i.e. in the event of risk of physical or psychological mistreatment).

The attribution of parental responsibility to the third person, that is, to the step-parent settled in lit. a is in accordance with the aforementioned exposed model whereby the State assigns a right to the step-parent in order to request parental responsibility. Hence, the spouse or partner of the legal parent living with the child is free to require or not parental responsibility. Having parental responsibility is depending only on his or her free will. In the comments on Article 3(28) MFC it is highlighted "the equality of a factual parent-child relationship with that of a legal one" (Schwenzer, 2006). On the opposite, the attribution of parental responsibility settled in lit. b is made directly by the State. However, in this case because it is made as a protection measure of the child, it is likely that the third person vested with parental responsibility is a public institution or at least a guardian ad litem.

Both academic legal instruments, when regulating parental responsibility make provisions by which, first, the best interest of the child principle (EPFLRPR 3:3, Article 3(1) MFC) should be regarded as a paramount consideration in all matters concerning the child' life, and, second, due appreciation should be given to the views expressed by the child depending on his or her age and maturity (EPFLRPR 3:4, Article 3(2) MFC) and, third, that the right of the child to be heard and to consent (EPFLRPR 3:6, Article 3(3) MFC) should be respected.

In conclusion, step-families are socially and legally accepted in whole Europe. Nevertheless, through the national legal systems and the soft law we can see that the adults' rights are set above of those rights of the child (Ferrer Riba, 2010). In other words, the concern both the national lawmakers and the academic works is how to legitimate the decisions taken by the adults in relation to the child' personal life. In fact, the best interests are that of the adults rather than that of the children.

\section{Concluding Observations}

After this presentation of the step-families within the legal framework of Europe, let me expose some concluding observations.

\section{The Future of the Step-Family in Europe}

As appointed by the OECD (OECD, 2012), which takes also into consideration the figures provided by EUROSTAT, regarding the structure of households for the future years 2025-2030, it should be foreseeable that the number of households with a sole adult person ${ }^{29}$, with one sole parent living with their children ${ }^{30}$ and the LAT ("living apart together") couples become more relevant. This future picture of households' structure is corresponding to the EUROSTAT forecasts, whereby there is actually and will be in the future a lack of intergenerational change (Eurostat, 2012). Thus, there is a small social room for step-families in the coming future.

The forecasts for the future of household structures of European citizens, provided by these official agencies, are in accordance with the "hamlet theory" described by anthropologists (Koch, 2009). Indeed, these have suggested that persons have reduced emotional rooms in their lives, at least, two relevant personal relationships, what means that once one of these rooms has been covered, even though it becomes free because of the breakup of the personal relationship, this is not covered again by someone else. Consequently, new personal relation-

\footnotetext{
${ }^{29}$ It is expected that in Europe the largest increase will be seen in England $(60 \%)$ and France $(75 \%)$.

${ }^{30}$ Households with a sole person would increase between $22 \%$ and $26 \%$ in Austria, Holland and Switzerland.

${ }^{31}$ In particular, in Germany and Finland.

(http://www.oecd.org/social/socialpoliciesanddata/41920080.pdf). Last checked: of 5 April 2013
} 
ships will be stated for a shorter period of time than those of relevant emotional meaning and the significance will be also of a minor importance.

In the light of these thoughts, it should be feasible that one person would have just one step-family. His or her personal emotional rooms will be completed with the original family and the second family. This is the reason why in the future instead of step-families they will raise the household structures that we have exposed above.

When this is the future, we should wonder about the need of a legal regulation of the step-families at all and if our answer is "yes, we need it" then we should see if it could be possible to approach the matter from the child's rights perspective.

\section{Direct Application of the EU Charter Both by the European Union Justice Court and National Courts}

As said by Article 6(1) of the TEU of Lisbon:

"The Union recognises the rights, freedoms and principles set out in the Charter of Fundamental Rights of the European Union of 7 December 2000, as adapted in Strasbourg, on 12 December 2007, which shall have the same legal value as the Treaties."

And by Article 52(2) EU Charter in the last drafting of 2010:

"Rights recognised by this Charter which are based on the Community Treaties or the Treaty on European Union shall be exercised under the conditions and within the limits defined by those Treaties."

The EU Charter has the same legal recognition within the EU as the Treaties, unless some exceptions concerning Poland and the United Kingdom are made. Thus, both national Courts and European Union Court of Justice shall directly apply the fundamental rights and freedoms stated by the EU Charter. Since 2010 there is no objection to this direct application when the EU Charter shall be considered instead of to be regarded just as an element of inspiration of the whole European Union and of the national legal systems.

What is being suggested here is that direct application of the EU Charter means that, when judging a case, in which fundamental rights of the child enter into conflict with those of the adult (Stalford \& Drywood, 2011), the EUCJ, in accordance with the proportionality test, could develop a body of judgments (jurisprudence) from the rights of the child viewpoint ${ }^{32}$. The ECtHR has settled the meaning of the proportionality test, that is, limiting a fundamental right is only legally possible when it is appropriate, necessary and proportionate to a legitimate aim (i.e, Ashingdane v. UK, A/93, 1985, 7 EHRR 528 para.57). Accordingly, Article 52(1) EU Charter provides that:

"Any limitation on the exercise of the rights and freedoms recognized by this Charter must be provided for by law and respect the essence of those rights and freedoms. Subject to the principle of proportionality, limitations may be made only if they are necessary and genuinely meet objectives of general interest recognized by the Union or the need to protect the rights and freedoms of others".

Hence, it is legally possible to limit the rights of the stepparent if conflicting with those of the child, when these limitations are aimed to objectives of general interests. As a reminder the EU has stated that one of these strategic objectives that

\footnotetext{
${ }^{32}$ One of the strategic objectives stated by the EU is to deserve priority to the application of children's rights.
}

deserves absolute priority is to protect and promote the rights of children in Europe ${ }^{33}$. Therefore, we agree with Eekelaar when he affirms that: "children are the innocent victims of the way the adults have conducted their lives. Therefore the need to weigh the respective interest according to the principle of proportionality must result in the children's interests being privileged or prioritized over the others" (Eekelaar, 2006).

In conclusion, the bedrock for the direct, vertical and effective application of children's rights by the EUCJ has been legally settled. The EUCJ should go forward and develop a solid and effective case Law to ensure the promotion of children's rights (Stalford \& Drywood, 2011), including effective measures, under Article 47 EU Charter, whereby:

"the fundamental right to effective judicial protection constitutes: i) general principle of Community Law".

\section{Prospective Regulation of the Step-Family in Europe}

As we have already exposed, there are some existing differences between the European national legal systems when attributing parental responsibilities to the step-parent. Therefore, it will be difficult to find a common core for regulating it at European level. For instance, the scholars that have drafted the EPFLRPR, have decided to introduce the two aforementioned patterns of having parental responsibility, among the different European jurisdictions, by the step-parent that exist (BoeleWoelki, 2008).

Nevertheless, there is a strong feeling that step-family should be legally strengthened in some way and the adult should be deserved some kind of legal protection when taking part in decisions concerning matters that affect the child' life.

In accordance with these two statements and keeping in mind the small social room for step-families in the future, in our opinion, the legal recognition of the "duty" of the step-parent to do what is reasonable in all circumstances of the case for the purpose of safeguarding or promoting the child' welfare, in a future harmonization of the European legislation, when he or she is currently living with him or her, would be enough. This "duty" could be drafted as a "general clause" without attributing parental responsibilities to the step-parent. This "general clause" could settle within either the section of a Family Act or of an Act regulating children's rights instead of being a section concerning parental responsibility. Seen as a "duty" the stepparent is not free to act or not, he or she shall act always "under the circumstances of the case".

\section{REFERENCES}

Bar-Hava, G., \& Pryor, J. (1998). Cinderella's challenge-adjustment to stepfamilies in the 1990s. Child and Family Law Quarterly, 10, $257-$ 280 .

Beck-Gernsheim, E. (2002). Reinventing the family (pp. 8-15). Cambridge \& Oxford.

Berstein, A. C. (1999). Reconstructing the brothers grimm: New tales for Stepfamily life. Family Process, 38, 415-429. doi:10.1111/j.1545-5300.1999.00415.x

Boele-Woelki, K. (2008). The CEFL principles regarding parental responsibilities: Predominance of the common core. In K. Boele-Woelki, \& T. Sverdrup (Eds.), European Challenges in Contemporary Family Law (pp. 70-71). Antwerp, Oxford \& Portland: Intersentia.

Boele-Woelki, K., Ferrand, F., González Beilfuss, C., Jänterä-Jareborg, M., Lowe, N., Martigny, D., \& Pintens, W. (2007). Principles of

\footnotetext{
${ }^{33}$ See: Communication on Strategic Objectives 2005-2009.
} 
European family law regarding parental responsabilities (pp. 70-77). Antwerp, Oxford \& Portland: Intersentia.

Boele-Woelki, K., Braat, B., \& Curry-Sumner, I. (2005). European family law in action, V. III: Parental responsibilities (pp. 77-80,389391, 477-480). Antwerp \& Oxford: Intersentia.

Cano Bazaga, E. (2013) El derecho de familia comunitarizado: La competencia judicial internacional de los tribunales españoles en material de crisis matrimoniales y responsabilidad parental. http://institucional.us.es/revistas/derecho/2/art_4.pdf

Cherney, I. D., Greteman, A. J., \& Traves, B. G. (2008). A cross-cultural view of adults' perceptions of children's rights. Social Justice Research, 21, 447-448. doi:10.1007/s11211-008-0079-7

De Cruz, P. (2010). Family law, sex and society. A comparative study of family law (pp. 325-329). London: Routledge.

Edwards, R. (2002). Creating stability for children in step-families: Time and substance of parenting. Conference Series, 6, 154-167.

Eekelaar, J. (2006). Family law and personal life (pp. 155-157). Oxford: Oxford University Press.

Eekelaar, J. (1991). Parental responsibility: State of nature or the nature of the state? Journal of Social Welfare \& Family Law, 13, 37-50. doi:10.1080/09649069108413929

Eekelaar, J. (1998). Do parents have a duty to consult? The Law Quarterly Review, 114, 337-341.

Eurostat (2010). Household structure in the EU (pp. 20-25). Brussels: Author.

Eurostat (2009). Reconciliation between work, private and family life in the EU (pp. 22-49). Brussels: Author.

Eurostat (2012). Figures for the future. 20 years of sustainable development in Europe? A guide for citizens (pp. 129-140). Brussels: Author.

Ferrer Riba, J. (2010). Principles and prospects for a European system of child protection. Indret. http://www.indret.com

Freeman, M. (2010). Disputing children. In M. Freeman (Ed.), Family values and family justice. Collected essays in law (p. 58). Surrey: Ashgate.

Goldscheider, F., \& Sassler, S. (2006). Creating stepfamilies: Integrating children into the study of union formation. Journal of Marriage \& the Family, 68, 275-291. doi:10.1111/j.1741-3737.2006.00252.x

Harris-Short, S., \& Miles, J. (2007). Family law. Texts, cases and materials (p. 767). Oxford: Oxford University Press.

Lowe, N. (2009). A study into the rights and legal status of children being brought up in various forms of marital or non-marital partnerships and cohabitation, Europe Council, Strasbourg, 21 September 2009.

http://www.coe.int/t/dghl/standardsetting/family/CJ-FA\%20_2008_\% 205\%20E\%2025\%2009\%2009.pdf

Koch, R. (2009). The 80/20 principle (2nd ed., pp. 223-224). Barcelona: Paidós.

Manning, W. D., Smock, P. J., \& Majumdar, D. (2004). The relative stability of cohabiting and marital unions for children. Population Research and Policy Review, 23, 135-159. doi:10.1023/B:POPU.0000019916.29156.a7

McGlynn, C. (2006). Families and the European Union. Law, politics \& pluralism (pp. 25-30,158-160). Cambridge: Cambridge University Press. doi:10.1017/CBO9780511495014

Melli, M. S., \& Brown, P. R. (2008). Exploring a new family form. The shared time family. International Journal of Law, Policy and the Family, 22, 231-269. doi:10.1093/lawfam/ebn002

Navas Navarro, S. (2010). Los derechos del menor en las familias reconstituidas. In S. Nasarre Aznar, R. Barrada Orellana, \& M. Garrido Melero (Eds.), El Nuevo derecho de la persona y de la familia en el Libro $2^{\circ}$ del Código civil de Cataluña (pp. 618-627). Barcelona: Bosch.

Navas Navarro, S. (2006). Matrimonio homosexual y adopción. Madrid: Reus.

Nelson, M. K. (2006). Single mothers "do" family. Journal of Marriage \& the Family, 68, 781-795. doi:10.1111/j.1741-3737.2006.00292.x

Organization for Economic Co-Operation and Development (2012). The future of families to 2030. OECD Publishing: Author.

Sanz Caballero, S. (2006). La familia en perspectiva internacional y Europea (pp. 10-40). Valencia: Tirant Lo Blanch.

Sarkisian, N. (2006). Doing family ambivalence: Nuclear and extended families in single mother's lives. Journal of Marriage \& the Family, 68, 804-811. doi:10.1111/j.1741-3737.2006.00295.x

Schwebel, A. I., \& Fine, M. A. (1991). A study of perceptions of stepparent role. Journal of Family Issues, 12, 43-57. doi: $10.1177 / 019251391012001004$

Schwenzer, I. (2006). Model family code. From a global perspective. intersentia. EFL, Antwerpen \& Oxford: Stämpfli.

Schwenzer, I. (2002). Art. 299, Basler Kommentar. In Honsell, Vogt, \& Geiser (Eds.), Zivilgesetzbuch I, Art. 1-456 ZGB (pp. 1583-1584). Basel, Genf \& München: Helbing \& Lichtenhahn.

Smith, L. (2008). Recent developments in child law. In K. BoeleWoelki, \& T. Sverdrup (Eds.), European challenges in contemporary family law (pp. 58-59). Antwerp, Oxford \& Portland: Intersentia.

Sosson, J. (1993). The legal status of step-families in continental European countries. In J. Eekelaar, \& P. Šarčević (Eds.), Parenthood in modern society. Legal and social issues for the first century (p. 397). Dordrecht: Martinus Nijhoff Publishers.

Stalford, H., \& Drywood, E. (2011). Using the CRC to inform EU law and policy-making. In A. Invernizi, \& J. Williams (Eds.), The human rights of children. From visions to implementation (pp. 211-234). London: Ashgate.

Wardle, L. D. (1993). The evolving rights and duties of step-parents: Making new rules for new families. In J. Eekelaar, \& P. Šarčević (Eds.), Parenthood in modern society. Legal and social issues for the first century (pp. 370-380). Dordrecht: Martinus Nijhoff Publishers. 